\title{
К ВОПРОСУ О ПОВЫШЕНИИ ЭФФЕКТИВНОСТИ ДЕЯТЕЛЬНОСТИ ПОЛИЦИИ ПО ОБЕСПЕЧЕНИЮ ТРАНСПОРТНОЙ БЕЗОПАСНОСТИ С ПОМОЩЬЮ ПРИМЕНЕНИЯ АДМИНИСТРАТИВНО-ПРАВОВОГО РЕГУЛИРОВАНИЯ
}

\begin{abstract}
Аннотация: Предметом исследования является административно-правовой механизм регулирования деятельности полиции по обеспечению транспортной безопасности. Реализация механизма административно-правового регулирования деятельности полиции по обеспечению транспортной безопасности - имеет немаловажное значение в обеспечении транспортной безопасности, от совершенствования нормативных предписаний, а также от их правильного и законного применения зависит уровень безопасности, состояние защищенности объектов транспортной инфраструктуры. Механизм административно-правового регулирования деятельности полиции по обеспечению транспортной безопасности включают в себя нормы административного права, административные правоотношения, акты применения норм административного права. Задачи, которые решает механизм административно-правового регулирования по обеспечению транспортной безопасности, главным образом связаны с задачами деятельности полиции. Методологической основой исследования является диалектический метод познания, использование которого обеспечивает восприятие правовых явлений в их развитии и взаимодействии; общенаучные методы (анализ, синтез, абстрагирование, обобщение, индукция и дедукция, аналогия), частично научные методы исследования в области правовых исследований (конкретно-социологический, системное, историческое, грамматическое, логическое толкование) Научная новизна диссертационного исследования заключается, прежде всего, в авторском подходе к исследованию понятия и содержания административно-правового регулирования деятельности полиции по обеспечению транспортной безопасности, изучению направлений деятельности полиции по обеспечению транспортной безопасности, а также возможности и перспективы использования зарубежного опыта деятельности полиции по обеспечению транспортной безопасности.

Ключевые слова: Транспорт, безопасность, полиция, административный, терроризм, угроза, деятельность, регулирование, акт, система.

Review: The subject of the study is the administrative and legal framework regulating the activities of the police in transport safety provision. Implementation of the mechanism of administrative and legal regulation of transport safety provision by the police is of great importance for transport safety. The degree of safety of transport infrastructure objects depends on the enhancement of regulations and their correct and legal implementation. The mechanism of administrative and legal regulation of the police activities in transport safety provision includes the rules of administrative law, administrative relationships and acts of administrative law enforcement. The missions of this mechanism are mainly related to the objectives of the police. The methodology of the study is based on the dialectical method of cognition which provides the perception of legal phenomena in their develop-
\end{abstract}




\section{Полицейская деятельность 2 • 2015}

ment and interaction; on the general scientific methods (analysis, synthesis, abstraction, generalization, induction and deduction, analogy), and special scientific methods of study in the field of legal research (the specific sociological method, the system, historical, grammatical, and logical interpretation). The scientific novelty of the research lies in the author's approach to the study of the concept and the content of administrative and legal regulation of the police in the sphere of transport safety, to the study of the police activities in the provision of transport safety, as well as to the opportunities and prospects of use of foreign experience of the police in transport safety provision.

Keywords: Regulation, activities, threat, terrorism, administrative, police, security, transport, act, system.

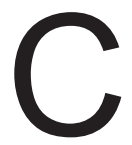

овременный этап развития российского общества характеризуется возрастающей ролью транспортной сфреры. Транспорт в Российской Федерации, наряду с другими инфрраструктурными отраслями, выполняет особую роль в социально-экономическом развитии нашей страны, обеспечивая условия жизнедеятельности общества. Устойчивое, эффрективное и безопасное функционирование транспортного комплекса является необходимым условием стабилизации и подъема экономики, обеспечения целостности государства, национальной безопасности и обороноспособности страны.

В наиболее общем виде национальные интересы Российской Федерации в транспортной сорере состоят:

- в удовлетворении потребностей личности, общества и государства в современном спектре транспортных услуг;

- в достижении путем технического перевооружения и модернизации транспортного комплекса высокой экономической эфффективности и безопасности транспортного процесса, в обеспечении доступности транспортных услуг на уровне, гарантирующем социальную стабильность, развитие межрегиональных связей и национального рынка труда, а также бесперебойный характер предоставления транспортных услуг;

- в приведении транспортной безопасности России к уровню международ- ных стандартов, что является необходимым условием для реализации транзитного потенциала транспортного комплекса, развития экспортноимпортных услуг, предупреждения и пресечения преступлений на транспорте, включая терроризм, обеспечение военной безопасности и укрепления России как великой державы.

Национальные интересы в транспортной сорере обеспечиваются институтами государственной власти, осуществляющими свои функции во взаимодействии с действующими на основе Конституции и законодательства Российской Федерации общественными организациями, субъектами транспортной инфраструктуры и специализированными органами в области транспортной безопасности.

Однако позитивные результаты укрепления стратегической роли и авторитета отечественного транспорта как внутри государства, так и на мировом рынке транспортных услуг могут быть достигнуты лишь в том случае, если он будет функционировать без сбоев.

Вместе с тем изменение современной геополитической ситуации и положения Российской Федерации в мировом сообществе выдвигают все новые требования к обеспечению транспортной безопасности, как к ведущему элементу системы обеспечения национальной безопасности. 
В этой связи не менее важной задачей в теоретико-методическом смысле является проблема понимания содержательного значения понятий «транспортная безопасность» и «обеспечение транспортной безопасности на объектах транспортной инфраструктуры».

Согласно Федерального закона от 9 фревраля 2007 г. «О транспортной безопасности», транспортная безопасность - состояние защищенности объектов транспортной инфраструктуры и транспортных средств от актов незаконного вмешательства.

Целями обеспечения транспортной безопасности являются устойчивое и безопасное функционирование транспортного комплекса, защита интересов личности, общества и государства в сорере транспортного комплекса от актов незаконного вмешательства.

Основными задачами обеспечения транспортной безопасности являются:

- нормативное правовое регулирование в области обеспечения транспортной безопасности;

- определение угроз совершения актов незаконного вмешательства; оценка уязвимости объектов транспортной инфрраструктуры и транспортных средств;

- категорирование объектов транспортной инфраструктуры и транспортных средств;

- разработка и реализация требований по обеспечению транспортной безопасности;

- подготовка и аттестация сил обеспечения транспортной безопасности;

- осуществление федерального государственного контроля (надзора) в области обеспечения транспортной безопасности;

- информационное, материально-техническое и научно-техническое обеспечение транспортной безопасности;

- сертифрикация технических средств обеспечения транспортной безопасности.
Объектами транспортной инфраструктуры на транспорте являются:

- железнодорожные, автомобильные вокзалы и станции;

- метрополитены;

- тоннели, эстакады, мосты;

- морские терминалы, акватории морских портов;

- порты, которые расположены на внутренних водных путях и в которых осуществляются посадка (высадка) пассажиров и (или) перевалка грузов повышенной опасности, судоходные гидротехнические сооружения;

- расположенные во внутренних морских водах, в территориальном море, исключительной экономической зоне и на континентальном шельфе Российской Федерации искусственные острова, установки, сооружения;

- аэродромы, аэропорты, объекты систем связи, навигации и управления движением транспортных средств;

- участки автомобильных дорог, железнодорожных и внутренних водных путей, вертодромы, посадочные площадки, а также иные обеспечивающие функционирование транспортного комплекса здания, сооружения, устройства и оборудования.

Однако реалии начала XXI века серьезно актуализировали проблему обеспечения транспортной безопасности, а именно - применение широкого спектра антитеррористических мероприятий по обеспечению безопасности на объектах транспортной инфраструктуры.

Выделим основные три группы этих мероприятий:

- профилактические меры;

- меры противодействия при попытке реализации террористического акта;

- ликвидация последствий, если этот акт все-таки был совершен.

Выполнение данных мероприятий требует не только дополнительных затрат и оснащения современными техни- 
ческими средствами, но и адекватных, упреждающих изменений в научных подходах к технологии и организации перевозочного процесса, оптимизации форм и методов деятельности сил (правоохранительных подразделений) обеспечения транспортной безопасности.

В целях разграничения объектов оперативного обслуживания и избежание споров между территориальными и транспортными подразделениями органов внутренних дел по вопросам работы в «пограничных» зонах, 10 июля 2008 г. Министерство внутренних дел Российской Федерации издало приказ № 598 «Об организации взаимодействия между органами внутренних дел на транспорте и МВД, ГУВД, УВД по субъектам Российской Федерации, органами внутренних дел в закрытых административно-территориальных образованиях, на особо важных и режимных объектах и разграничения объектов оперативного обслуживания», в котором четко обозначены эти границы.

Одним из звеньев в обеспечении транспортной безопасности на объектах транспорта является Главное управление на транспорте Министерства внутренних дел Российской Федерации - структурное подразделение МВД России, ответственное за обеспечение транспортной безопасности на объектах железнодорожного, водного и воздушного транспорта.

Основными задачами Главного управления являются: организация и участие в формировании основных направлений государственной политики в области обеспечения правопорядка на объектах транспорта; обеспечение совершенствования нормативно-правового регулирования в области обеспечения правопорядка на объектах транспорта; организация в пределах своих полномочий противодействия преступности, охраны общественного порядка и обеспечения общественной безопасности на объектах транспорта; участие в пределах своих полномочий в реализации мероприятий по предупреждению и пресечению актов незаконного вмешательства на объектах транспорта; обеспечение в пределах своих полномочий межведомственного взаимодействия по вопросам транспортной безопасности; управление органами внутренних дел на транспорте; организационно-методическое обеспечение деятельности органов внутренних дел на транспорте, а по вопросам транспортной безопасности - органов внутренних дел, обеспечивающих правопорядок и общественную безопасность на территориях (объектах) метрополитенов ${ }^{[1]}$.

Главное управление на транспорте состоит из четырех управлений: оперативно-розыскного, организационноконтрольного, управления организации борьбы с преступностью на транспорте и управления организации охраны общественного порядка. Непосредственно на местах (вокзалах, станциях, аэропортах, портах и т. п.) управление представляют линейные отделы полиции, общее количество которых составляет около полутысячи. Линейные отделы полиции находятся в подчинении региональных управлений внутренних дел на транспорте (УВДТ), которые в процессе безопасного функционирования транспорта выполняют стоящие перед ними задачи, как общие, так и специальные.

Основными законодательными и нормативными правовыми актами регулирующими деятельность полиции по обеспечению транспортной безопасности являются: Конституция Российской Федерации; Федеральный закон от 30 декабря 2001 г. № 195-Ф3 «Кодекс Российской Федерации об административных правонарушениях»; Федеральный закон от 9 фревраля 2007 г. № 16-Ф3 «О транспортной безопасности»; Федеральный закон от 28 декабря 2010 г. № 390-Ф3 
"О безопасности»; Федеральный закон от 7 февраля 2011 г. № 3-Ф3 «О полиции»; Федеральный закон от 10 января 2003 г. № 17-Ф3 «О железнодорожном транспорте в Российской Федерации»; Федеральный закон от 10 января 2003 г. № 18-Ф3 «Устав железнодорожного транспорта Российской Федерации»; постановление Правительства Российской Федерации от 10 декабря 2008 г. № 940 «Об уровнях безопасности объектов транспортной инфраструктуры и транспортных средств и о порядке их объявления (установления)»; постановление Правительства Российской Федерации от 4 октября 2013 г. № 880 «Об утверждении положения о федеральном государственном контроле (надзоре) в области транспортной безопасности»; распоряжение Правительства Российской Федерации от 30 июля 2010 г. № 1285-р «Комплексная программа обеспечения безопасности населения на транспорте»; приказ МВД России от 10 июля 2008 г. № 598 «Об организации взаимодействия между органами внутренних дел на транспорте и МВД, ГУВД, УВД по субъектам Российской Федерации, органами внутренних дел в закрытых административно-территориальных образованиях, на особо важных объектах и разграничении объектов оперативного обслуживания»; совместный приказ Министерства транспорта Российской Федерации, ФСБ России, Министерства внутренних дел Российской Федерации от 5 марта 2010 г. № 52/ 112/ 134 «Об утверждении Перечня потенциальных угроз совершения актов незаконного вмешательства в деятельность объектов транспортной инфраструктуры и транспортных средств»; совместный приказ Министерства внутренних дел Российской Федерации, Министерства транспорта Российской Федерации от 27 декабря 2013 г. № 1022/487 «Об утверждении Инструкции по организа- ции работы нарядов полиции линейных управлений (отделов) МВД России на железнодорожном, водном и воздушном транспорте и работников локомотивных и поездных бригад по обеспечению правопорядка в поездах дальнего следования и пригородного сообщения».

Следует отметить, что законодательная база обеспечения безопасности на транспорте включает в себя как уголовно-правовые, так и административно-правовые меры. Безопасность объектов транспортной инфраструктуры поставлена под уголовно-правовую охрану не только в статье $263^{1}$ УК РФ. Обеспечение данного вида безопасности осуществляется и с помощью уголовно-правовых запретов недоброкачественного ремонта объектов транспортной инфраструктуры (статья 266 УК РФ); приведения в негодность и блокирования объектов транспортной инфраструктуры (стать 267 УК РФ); совершения террористического акта (статья 205 УК РФ) и диверсии (статьи 281 УК РФ). В Кодексе Российской Федерации об административных правонарушениях также имеется соответствующая Глава 11 «Административные правонарушения на транспорте».

Как уже отмечалось ранее, основными задачами сотрудников полиции на транспорте являются вопросы противодействия терроризму, охраны общественного порядка и обеспечение общественной безопасности, безопасности пассажирских и грузовых перевозок, противодействия распространения оружия, взрывчатых веществ, боеприпасов и наркотиков на всех видах транспорта: железнодорожном, воздушном, морском и речном.

Заметим, что среди прав, предоставленных полиции на транспорте, в соответствии со статьей 13 указанного закона, предусмотрены как общие полицейские права, так и специальные, 


\section{Полицейская деятельность 2 • 2015}

п.16 предусмотрено право принимать участие в досмотре пассажиров, их ручной клади и багажа на железнодорожном, водном или воздушном транспорте, метрополитене либо осуществлять такой досмотр самостоятельно в целях изъятия вещей и предметов, запрещенных для перевозки транспортными средствами; п.27 предписано проводить при осуществлении контроля за соблюдением авиационной безопасности в области гражданской авиации проверки соблюдения правил предполетного досмотра, пропускного и внутриобъектного режимов; запрашивать и получать от руководителей организаций, служб авиационной безопасности аэродромов, аэропортов, авиационных предприятий, подразделений ведомственной охраны фредерального органа исполнительной власти, уполномоченного в области транспорта, а также от перевозчиков, грузоотправителей и иных организаций необходимые документы и информацию; выдавать руководителям организаций обязательные для исполнения предписания об устранении выявленных нарушений требований авиационной безопасности и проверять исполнение этих предписаний; при наличии информации о возможном нарушении требований авиационной безопасности на воздушном судне сопровождать его во время полета; задерживать багаж, грузы и почту, содержащие предметы и вещества, запрещенные к перевозке воздушными судами.

Как уже ранее отмечалось, деятельность полиции на транспорте - комплексная система обеспечения транспортной безопасности и имеет ярко выраженную предупредительную направленность. В этой системе важная роль принадлежит административно-правовому регулированию деятельности полиции по обеспечению общественной безопасности и общественного порядка.
А. П. Коренев отмечал, что административно-правовое регулирование представляет собой «процесс последовательного использования административно-правовых средств для достижения целей регулирования поведения участников общественных отношений» ${ }^{[2]}$.

Механизм административно-правового регулирования деятельности полиции - система правовых средств, при помощи которых осуществляется правоохранительная деятельность.

Механизм административно-правового регулирования деятельности полиции по обеспечению транспортной безопасности включают в себя нормы административного права, административные правоотношения, акты применения норм административного права. Задачи, которые решает механизм административно-правового регулирования по обеспечению транспортной безопасности, главным образом связаны с задачами деятельности полиции.

Как отмечает М. В. Костенников, «законодательная база как основа административно-правового регулирования транспортной безопасности должна отражать появление транспортных предприятий различных организационноправовых фрорм и фрорм собственности, обеспечивать эфффективное взаимодействие предприятий транспорта, государственную защиту прав потребителей транспортных услуг, безопасность транспортного процесса и охрану окружающей среды» ${ }^{[3]}$.

Исходя из вышеизложенного, следует отметить, что реализация механизма административно-правового регулирования деятельности полиции по обеспечению транспортной безопасности - имеет немаловажное значение в обеспечении транспортной безопасности, от совершенствования нормативных предписаний, а также от их правильного и законного применения зависит 
уровень безопасности, состояние защищенности объектов транспортной инфрраструктуры.

Подводя итог рассмотрению реализации механизма административно-правовой регулирования, необходимо подчеркнуть, что проводимые исследования позволят глубже изучить нормы административного права, административные правоотношения, а также акты примене- ния норм административного права, как элементов механизма административноправового регулирования деятельности полиции на транспорте. На наш взгляд необходимо в целях совершенствования механизма реализации данного института разработать рекомендации по повышению эфффективности правоприменительной деятельности в рассматриваемой сорере.

\section{Библиография:}

1. Сайт http://www.mvd.ru. (Дата обращения 03.03.2015 г.).

2. Коренев А. П. Административное право России. - М., 2000. - С.40.

3. Костенников М. В., Трофимов О. Е. Правовое регулирование транспортной безопасности и роль полиции в ее обеспечении // NB: Административное право и практика администрирования. - 2013. - № 9. - С. 18-52.

4. Адмиралова И.А., Трофимов О.Е. К вопросу о защите прав граждан в сфере обеспечения транспортной безопасности федеральными органами исполнительной власти // Право и политика. - 2014. - 8. - C. 1098-1106. DOI: 10.7256/1811-9018.2014.8.11549.

\section{References (transliterated):}

1. Korenev A. P. Administrativnoe pravo Rossii. - M., 2000. - S.40.

2. Kostennikov M. V., Trofimov O. E. Pravovoe regulirovanie transportnoi bezopasnosti i rol' politsii v ee obespechenii // NB: Administrativnoe pravo i praktika administrirovaniya. - 2013. - № 9. - S. $18-52$.

3. Admiralova I.A., Trofimov O.E. K voprosu o zashchite prav grazhdan v sfere obespecheniya transportnoi bezopasnosti federal'nymi organami ispolnitel'noi vlasti // Pravo i politika. - 2014. - 8. - C. 1098-1106. DOI: 10.7256/1811-9018.2014.8.11549. 